\title{
REPRESENTACIONES SOCIALES DE LAS FAMILIAS ACERCA DE LA PARTICIPACIÓN POLÍTICA*
}

Yolanda Rosa Morales Castro

* Este producto muestra los resultados del capítulo cuatro de la tesis doctoral de la autora intitulada: La familia como agente de socialización en el sistema político de Colombia a partir de la instauración de la democracia participativa 1991-2014 en el marco del doctorado en Ciencia política de la Universidad de Zulia en Maracaibo, Venezuela.

1 Trabajadora Social. Especialista en Estudios Pedagógicos. Magistral en Desarrollo Familiar. Doctora en Ciencia Política. Docente e investigadora del grupo de Estudios de Genero, Familia y Sociedad de la Universidad Simón Bolívar. ymorales@unisimonbolivar.edu.co 


\section{RESUMEN}

La investigación estuvo mediada por la forma en que las familias concibieron la participación política mediante las representaciones sociales de sus miembros y la influencia de los agentes de socialización política, en especial la familia. Para el análisis de la categoría y dimensiones, se trabajó con familias residentes en todos los estratos socioeconómicos de Barranquilla, con las cuales se desarrollaron entrevistas a profundidad y el dibujo creativo con los niños y adolescentes; en ambas técnicas se relacionaron las dimensiones de información, actitud y campo de representación y otras categorías que emergieron en el ambiente natural de las familias. Teniendo en cuenta las apreciaciones teóricas, conceptuales y los resultados expuestos en este capítulo, se concluyó que varios son los aspectos que se integran en un proceso de participación política, donde el eje central es el ciudadano y la comunidad, lo cual conlleva a la necesidad de socializar todas aquellas actividades que estimulan una actitud de participación política que conduzca a empoderarse y movilizarse, si es el caso, a fin de resignificar en gran medida las representaciones sociales que hoy se tienen sobre el tema. Se finaliza el estudio con un tinte ideológico y político en defensa de la democracia como modo de vida.

Las representaciones sociales ${ }^{2}$ (RS) se han consolidado como formas de conocimiento de tipo teórico-práctico que circulan en los intercambios de la vida cotidiana en las sociedades contemporáneas para el entendimiento, la descripción y dominio de los hechos de la vida común de las personas.

2 A lo largo del texto se usa la noción de representaciones sociales en plural o, representación social en singular -cuando se habla de casos específicos y concretos- en dos sentidos vinculados, a saber: como constructo epistemológico y como realidad empírica de cara a los procesos de socialización política experimentados por la familia. 
Mucho se ha discutido respecto al tema de las RS, de tal manera que sus teóricos e investigadores la han definido pretendiendo aclarar la complejidad del concepto.

Durkheim (2000) toma el concepto para entender el fenómeno que tiene su origen en las relaciones sociales que establecen los individuos en una sociedad. Señala que las representaciones colectivas son: Realidades que sostienen con su sustrato íntimas relaciones y cuya autonomía no puede ser sino relativa.

Teniendo en cuenta lo anterior, el objetivo del estudio es interpretar las representaciones sociales que tienen los miembros de las familias con relación a la participación política.

Otro de los pioneros en trabajar el tema de las RS fue Serge Moscovici, quien en su obra El Psicoanálisis, su imagen y su público realizó una aproximación a la definición de las representaciones sociales:

[...] como una modalidad particular del conocimiento, cuya función es la elaboración de los comportamientos y la comunicación entre los individuos. La representación es un corpus organizado de conocimientos y una de las actividades psíquicas gracias a las cuales los hombres hacen inteligible la realidad física y social, se integran en un grupo o en una relación cotidiana de intercambios, liberan los poderes de su imaginación. $(1979$, p.16)

Estos planteamientos conciben las representaciones sociales como una modalidad de pensamiento práctico que sintetiza la subjetividad social y está orientada hacia la comunicación, la comprensión y el dominio de su entorno social. Este concepto vigente es complementado posteriormente por el mismo Mosco- 
vici donde afirma que:

Las RS son imágenes que condensan significados que actúan como sistemas de referencia que permite interpretar lo que sucede, categorías para clasificar y teorías que sustentan el mundo. En otras palabras, una manera de pensar e interpretar la realidad cotidiana. (1986, p.18)

Mediante esta apreciación, las RS se entienden como la manera en que los sujetos sociales aprehenden los acontecimientos de la vida diaria, las características del medioambiente, las informaciones que en él circulan desde el entorno próximo o lejano.

Las características de las RS que propone Moscovici (1986) en su texto Psicología Social // sustentan la tesis anteriormente mencionada, puesto que estas corresponden a la representación de un objeto entendido como cosa o persona, tienen carácter constructivo, autónomo y creativo y, por último, tienen el carácter de imagen, es decir, figuras con un conjunto de rasgos que las definen. Así, las personas van introduciendo en las representaciones ideas, valores y creencias de su grupo, expresando con ello el sentido que le dan a sus experiencias.

Otra estudiosa significativa de las RS es Jodelet, quien explica que:

Las representaciones sociales son entendidas como el conjunto de creencias, valores y saberes que hemos aprendido sobre los acontecimientos de la vida diaria, de las personas que se encuentran en nuestro entorno y de nuestra experiencia particular, y en todo caso se encuentra mediado por un lenguaje social. (1993, p.475)

Relacionando los anteriores conceptos, vemos que el entorno 
social juega un papel fundamental en la producción y reproducción de las RS, porque en él también se construye conocimiento a través del sentido común proveniente del intercambio de la vida cotidiana -relaciones intersubjetivas-, dando origen a fenómenos colectivos que ocurren en la intercepción entre lo psicológico y lo social. En tal sentido:

[...] la necesidad de saber a qué atenerse ante el mundo que nos rodea, puesto que es necesario adaptarse, actuar en él, controlarlo física e intelectualmente y resolver los problemas que nos plantea; por tal motivo, se construyen representaciones ya que ante este mundo de objetos, personas, sucesos e ideas, no se está equipado únicamente de automatismos, ni se está aislado en un medio eminentemente social, sino que se comparte con otros, se apoya en ellos para comprenderlo, afrontarlo y controlarlo. Por eso decimos que las representaciones son sociales y por eso son tan importantes en la vida cotidiana. (Jodelet,1993, p.25)

Lo anterior permite inferir que la forma de actuar y de pensar de cada individuo, está relacionada con las experiencias vividas y por aquellas que observan en los demás, situación que se potencializa con la comunicación entre miembros de un grupo o integrantes de una cultura, quienes tienen un mismo lenguaje, el cual puede ser a través de palabras, omisiones, silencios, imágenes o gestos, o una combinación de ellos.

Es importante resaltar que las RS orientan en la manera de significar, designar y definir muchos aspectos de la realidad diaria, la forma cómo interpretarla e influir sobre ella y, en caso contrario, tomar una posición ante ellos y defenderla. Por tal razón las RS implican:

Sistemas cognoscitivos con una lógica y un lenguaje propios, para 
él no representan simplemente opiniones acerca de, 'imágenes de', o 'actitudes hacia' sino 'teorías o ramas del conocimiento' con derechos propios para el descubrimiento y la organización de la realidad. Sistemas de valores, ideas y prácticas con una función doble. Primero, establecer un orden que permita a los individuos orientarse en su mundo material y social y dominarlo; segundo, posibilitar la comunicación entre los miembros de una comunidad proporcionándoles un código para el intercambio social y un código para nombrar y clasificar sin ambigüedades los diversos aspectos de su mundo y de su historia individual y grupal. (Farr, 1984, p.3)

La noción anterior, complementa lo dicho por los teóricos que le antecedieron, dándole un amplio valor en términos de significado al lenguaje propio y a las teorías o ramas del conocimiento, aduciendo su aporte para el descubrimiento y la organización de la realidad. Los conceptos de RS establecidos por los autores no son excluyentes, ni contradictorias entre sí, por el contrario, son incluyentes al referirse a aspectos diferentes pero presentes en todos los fenómenos de las RS.

\section{DIMENSIONES DE LAS REPRESENTACIONES SOCIALES}

Las representaciones sociales definidas por Moscovici (1979, p.49) como "Universos de opinión", pueden ser analizadas con fines didácticos y empíricos en tres dimensiones: la información, el campo de representación y la actitud.

a) La información:

Es la organización o suma de conocimientos con que cuenta un grupo acerca de un acontecimiento, hecho o fenómeno de naturaleza social. Conocimientos que muestran particularidades en cuanto a cantidad y a calidad de los mismos; carácter estereotipado o 
difundido sin soporte explícito; trivialidad u originalidad en su caso. Dimensión o concepto, se relaciona con la organización de los conocimientos que posee un grupo respecto a un objeto social. (Moscovici, 1979, p.45)

Esta dimensión conduce necesariamente a la riqueza de datos o explicaciones que sobre la realidad se forman los individuos en sus relaciones cotidianas.

b) El campo de representación:

Expresa la organización del contenido de la representación en forma jerarquizada, variando de grupo a grupo e inclusive al interior del mismo grupo. Permite visualizar el carácter del contenido, las propiedades cualitativas o imaginativas, en un campo que integra informaciones en un nuevo nivel de organización en relación a sus fuentes inmediatas. (Moscovici, 1979, p.45)

El campo de representación nos remite a la idea de imagen, de modelo social, al contenido concreto y limitado de las proposiciones que se refieren a un aspecto preciso del objeto de representación.

c) La actitud:

Es la dimensión que significa la orientación favorable o desfavorable en relación con el objeto de la representación social. (Moscovici, 1979, p.45)

La actitud se puede considerar, por lo tanto, como el componente más aparente, fáctico y conductual de la representación y como la dimensión que suele resultar más generosamente estudiada por su implicación comportamental y de motivación, entre otras. Estas tres dimensiones de manera separada no son muy 
significativas, pero integradas soportan la hipótesis planteada por Moscovici que al verse en conjunto, completa la estructura de la representación en términos de contenido y de sentido.

\section{PROCESOS DE LA REPRESENTACIÓN SOCIAL}

Dos son los procesos que permiten la construcción de las RS: la objetivación y el anclaje. La objetivación es el proceso mediante el cual los elementos abstractos conceptuales se transforman en imágenes, elementos icónicos; lo abstracto sufre una especie de reificación o cosificación y se convierte en algo concreto y familiar, lo esencialmente familiar y ajeno (Jodelet, 1993).

"Involucra el proceso social de comunicación y el discurso colectivo" (Abric, 2001, p.11). Por esta razón, retiene de manera selectiva ciertos puntos de información recibida: "Para desembocar en un arreglo particular de conocimientos respecto a ese objeto" que conformarán el núcleo central (Wagner, 2011, p.160).

El anclaje actúa integrando las informaciones que llegan mediante el proceso previamente descrito a nuestro sistema de pensamiento ya configurado. El lenguaje cotidiano es ver lo nuevo con lentes viejos. Este proceso permite integrar las nuevas representaciones a todo el sistema representacional pre-existente, reconstruyendo permanentemente nuestra visión de la realidad (Jodelet, 1993).

En opinión de González (2010), por su naturaleza social, estos procesos se encuentran inmersos en un contexto histórico ya que poseen una historia como forma de conocimiento, porque surgen, se desarrollan y transforman para movilizar conjuntos sociales e influenciar en instituciones concretas del orden político y social de los modos de vida. 
A través del proceso de objetivación se convierte lo abstracto y extraño en concreto y familiar y, a través del proceso de anclaje se incorporan las cosas nombrándolas, clasificándolas y enraizándolas en lo social de acuerdo al significado y utilidad que se les otorga desde la sociedad.

\section{LAS REPRESENTACIONES SOCIALES Y LA FAMILIA}

En la familia, el sujeto inicia su vida, sus primeras experiencias y relaciones, que al mismo tiempo están conectadas a una sociedad; en ella se construyen la identidad individual y social de las personas, situación relevante para la organización social y para la psicología de los individuos.

Son muchas las definiciones que han surgido a través de la historia en torno al concepto de familia, el cual se ha redefinido teniendo en cuenta las características sociales predominantes en cada momento histórico. Para Gough (1982, p.25) "La familia se le define como una pareja u otro grupo de parientes adultos que cooperan en la vida económica y en la crianza y educación de los hijos, la mayor parte de los cuales o todos ellos utilizan una morada común."

La institución familiar es relevante en el marco de la sociedad, ya que todo individuo vive, a lo largo de su existencia, inmerso en una red de relaciones y actividades conectadas de una forma u otra con lazos familiares.

La familia, tanto desde el punto de vista biológico de la reproducción de la especie, como desde el ángulo social de la transmisión de la cultura, constituye el eje central sobre el que gira el ciclo vital, de acuerdo con el cual transcurre nuestra existencia como individuos y asegura la continuidad de la sociedad de generación en generación”. (Ramírez, 2015, p.32) 
Respecto a la transmisión de la cultura o su socialización, se puede deducir que la sociedad y la familia se influyen mutuamente; la sociedad aporta condiciones económicas, socioculturales, normas y valores, y es en la familia como núcleo básico de esta sociedad, donde se concretizan sistemas de creencias y valores que se van transmitiendo de una generación a otra, en el marco de un proceso dinámico de redefinición y resignificación de los mismos. Por esta razón:

La familia es el primer lugar de transmisión de la cultura. Forma parte de una sociedad que se rige por normas. Estas son modos de regulación de la conducta informal que se van generando fundamentalmente por la tradición. La familia y particularmente la pareja, deben actuar de tal forma que aseguren la transmisión de estas normas a través de la función de socialización, esto es mediante la crianza y educación de los hijos. (García, 2008, p.17)

En la plataforma de esa transmisión de cultura, el tema de la socialización política, permite hacer referencia a cómo, qué y cuándo aprende la familia acerca de la política y lo político; esto es, un proceso de enseñanza-aprendizaje e interiorización de valores, símbolos y actitudes frente a la política. Visto así, nos situamos ante un proceso cultural que intenta insertar al individuo en su sociedad al hacerlo partícipe del código de valores y actitudes que en ella son dominantes.

Muy a pesar de que la familia es una institución privada y de singularidad, se encuentra inmersa en la sociedad de tal manera que debe ajustarse a las normas y modos de vida presentes en ella.

La socialización política transmitida por las familias puede influenciar en las representaciones sociales de sus miembros, 
teniendo en cuenta que la consideración más importante de la familia como agente de socialización política es su relación con el sistema político, en tanto que marco referencial en el que se estructura la organización de la comunidad, la gestión de sus conflictos y la administración de sus recursos.

(...) La familia es entendida como el grupo primario por excelencia, diferenciándose de los demás grupos por su evolución bio-social en una cultura particular. La familia no es única sino polimórfica y multifuncional, lo que se expresa en la variedad de tipologías. (Quintero, 1994, p.19)

Hoy en día no debemos hablar de familia sino de familias, porque existe en nuestra sociedad una tipología ampliada de familias $^{3}$ que adquieren dinámicas diferentes por su estructura, roles y tipos de relaciones entre sus miembros. Es importante resaltar las tipologías familiares en el proceso de socialización política, ya que adquieren significancia en la transmisión de valores políticos en la medida en que sus integrantes desarrollen procesos de socialización política al interior de ellas.

Cuando la familia es nuclear, por ejemplo, su estructura está conformada por los padres e hijos; los primeros se encargan de transmitir todo el proceso de socialización política, mientras que en la familia extensa, el proceso de socialización política es transmitido por varios integrantes pertenecientes a diferentes generaciones, como los abuelos, tíos y primos, entre otros.

Esta tipología familiar muestra que las familias han tenido grandes transformaciones; sin embargo, las investigaciones específicas en el campo de la socialización política, han subrayado

3 Tipología familiar: Familia nuclear, extensa o conjunta, trigeneracional, ampliada, familias homosexuales, padrastral o madrastral, familias monoparentales entre otras. 
la importancia de la familia en el proceso de adquisición de normas políticas en particular. La institución familiar se ha adaptado a nuevas realidades sociales.

(...) Hay un mayor reconocimiento de la autonomía de los hijos, la tolerancia de los padres hacia ellos es muy grande en la actualidad y comparativamente mucho mayor que antes. Se trata de una socialización que es sin duda menos autoritaria, menos directiva y, por tanto la transmisión de los valores se hace mejor. (Percheron, 1990, p.131)

En estos momentos las familias no esperan de los hijos ese apego incondicional a las ideas de sus padres, sino que los orientan para que ellos desarrollen su personalidad y puedan tomar sus propias decisiones en el marco de una socialización menos autoritaria y más democrática, lo cual es una plataforma ideal para socializar ${ }^{4}$ los valores y actitudes políticas; sin embargo las familias también están influenciadas por los factores ambientales, los cuales son determinantes en el proceso de socialización política.

Esta afirmación se puede evidenciar en el estudio empírico desarrollado sobre socialización política transferido por las familias de los estudiantes de la Universidad Simón Bolívar, donde los sujetos estudiados coinciden que los valores políticos han sido socializados en gran medida al interior de la familia y sin imposición, ya que participan libremente en política, sin sentir presión por parte de ellos (Ríos y Morales, 2015).

La socialización temprana influye sobre las percepciones de

4 Anduiza y Bosch (2015, p.191) "La socialización política se refiere al proceso de consolidación de valores explícitamente políticos del ciudadano". Los autores consideran como valores políticos la identificación con un partido desde los padres hacia los hijos, la ideología de izquierdaderecha o el nacionalismo. 
los miembros de las familias, pero no implica que la internalización de códigos valorativos, los esquemas perceptivos y las actitudes no puedan sufrir modificaciones producto de experiencias posteriores más directamente vinculadas con el área política.

Las imágenes que construyen los miembros de las familias acerca de la participación política no son arbitrarias sino que provienen del producto de razonamientos de sentido común que incluyen componentes psicosociológicos que conjuntamente con la teoría de las representaciones sociales, constituyen sistemas cognitivos y modelos interpretativos de la realidad, en los que es posible reconocer la presencia de estereotipos, opiniones, creencias, valores y normas que suelen manifestarse en las actitudes de las personas, de manera positiva o negativa hacia el sistema político, sus estructuras y procesos concretos.

\section{REPRESENTACIONES SOCIALES Y LOS AGENTES SECUNDARIOS DE SOCIALIZACIÓN POLÍTICA}

Esta noción de las RS da cuenta de la influencia que ejerce el medio o contexto sociopolítico en la forma de pensar e interpretar acontecimientos sociales. Este tipo de creencias y pensamientos no son elaborados personalmente, sino que resultan de un producto de las interacciones y la comunicación social. Por ello, Castorina (2003) plantea que las RS anteceden a cada persona, quienes se apropian de ellas durante las prácticas institucionales o grupales en las que participan. Las Representaciones Sociales (RS) constituyen la categoría que transversaliza todo el contenido, puesto que esta concierne:

A la manera como nosotros, sujetos sociales, aprendemos los acontecimientos diarios, las características del medio ambiente, las informaciones que en él circulan y a las personas de nuestro entorno próximo y lejano. (Moscovici, 1986, p.473) 
También, el sentido común juega un papel significativo en el tema de las RS, ya que es aquel conocimiento que se va construyendo mediante los sucesos y eventos que son producto de nuestra experiencia y por todos aquellos aspectos que forman parte de nuestras tradiciones: comunicación verbal o no verbal entre las personas con quienes nos relacionamos. El conocimiento social es de todos porque traspasa las barreras geográficas para ser conocido por otras comunidades mediante los medios masivos de comunicación. No obstante, varía de una nación a otra.

La asociación entre las RS y los medios como agentes de socialización política, se reflejan en la forma en que las distintas RS son llevadas a la población y se manifiestan de manera precisa o transformada por dichos medios, es decir, que se mantiene en la información brindada, las ideas del mundo socialmente compartidas, o bien se integran nuevas formas de apreciación del mundo que se generan a partir de avances tecnológicos y descubrimientos científicos.

Las mismas RS que se tienen frente al mundo y los demás, operan como un sistema que se retroalimenta en la interacción individuo-sociedad, y se fortalecen o transforman mediante la comunicación.

Los medios de comunicación y las redes sociales juegan un papel fundamental como agente secundario de socialización política, sobre todo la televisión, ya que son influyentes desde dos aspectos: los programas dirigidos a grupos de edades son más frecuentes, creando incluso subculturas, y sus contenidos suelen tematizarse en los grupos de pares; en otro sentido, juegan como filtros de la información que llega a niños, jóvenes o adultos. 
Moscovici (1979) hace referencia al rol de la comunicación social, porque está relacionada con los cambios e interacciones que propician la construcción de un universo simbólico consensuado y conlleva a los sujetos a los fenómenos de influencia y de pertenencia social, que son significativos en la elaboración de sistemas intelectuales y sus formas prácticas en la vida cotidiana, en el marco de las relaciones intersubjetivas.

Los medios de comunicación, mediante su rol socializador de la política, pueden incidir de una u otra manera, en el comportamiento de los miembros de la familia al momento de participar en la vida política.

Otro agente de socialización política influyente son los partidos políticos, porque actúan como espejo para la construcción de las representaciones sociales, por su agilidad en moldear lo que quieren mostrar a la sociedad y se han preparado para ejercer un papel protagónico en su proceso socializador, mediante el liderazgo político individual o colectivo y las estrategias de marketing.

Los individuos tienen un mundo de apreciaciones basadas en la construcción de sus representaciones y tienen la libertad de expresarlas mediante un marco valorativo o sistema axiológico, independiente de los agentes socializadores que hayan contribuido para ello.

\section{REPRESENTACIONES SOCIALES ACERCA DE LA PARTICIPACIÓN POLÍTICA}

Acerca de la participación política las RS juegan un papel importante en la dinámica política. 
La política incluye aspectos como la participación, entendida como el conjunto de actividades, interacciones, comportamientos, acciones y actitudes que se dan en una sociedad de forma individual o colectiva por los ciudadanos, grupos, partidos e instituciones, las cuales van dirigidas a explicar, demandar, influir o tomar parte en el proceso de decisiones políticas, en el reparto autoritario de valores. (Losada, 2008, p.348)

Es importante resaltar que la participación electoral es una de las formas de participación política ${ }^{5}$, la cual es considerada como una serie de actividades de carácter voluntario mediante el cual los miembros de la sociedad participan en la elección de sus gobernantes, quienes obtienen del sufragio popular su legitimidad de origen. En el lenguaje político es común confundir estos dos términos, situación que se puede observar en el mar-

214 co de esta investigación donde la mayoría de los entrevistados tiene interiorizado como única forma de RS de la participación política, a la participación electoral (sufragio).

La actitud política juega un papel fundamental en el tema de la participación, ya que se relaciona con las creencias y valores que interiorizan los sujetos para guiarlos en la construcción de su pensamiento respecto a un asunto. La actitud política con que se construyen las RS proviene a partir de las predisposiciones adquiridas por los ciudadanos, las cuales se manifiestan a través de distintas formas de participación política. En este sentido:

(...) La participación política es asociada con una forma diferente de hacer política, la cual busca el mantenimiento de la comunidad a través de diversas actividades como el establecimiento de la comunicación pública para la solución de las disputas existentes y la coo-

5 Por la falta de claridad conceptual que ronda el espectro político, es frecuente confundir un evento electoral (día de las elecciones) con la participación política, aduciendo que esta última fue alta o baja, sin detenerse a precisar que la participación electoral es una de las formas o expresiones de la participación política, entre otras. 
peración entre los miembros individuales y grupales pertenecientes a la comunidad en cuestión. (Franco y Flórez, 2009, p.82-83)

Otro aspecto fundamental en el ejercicio de la participación política está relacionado con la configuración de la subjetividad política en procesos que aproximan los sentidos y las prácticas de acción política en un orden democrático determinado.

En el marco del potencial político se otorga reconocimiento a la acción política como algo inherente al ser humano -recordemos el zoon politikón del que nos hablaba Aristóteles como protagonista de la polis, desde la antigüedad clásica-, es decir, parte del reconocimiento de la ciudadanía plena ${ }^{6}$ de los niños, niñas, adolescentes y jóvenes.

La política se asume como un ejercicio innegociable que parte de lo individual y se expresa en lo colectivo, cuyo fin es la configuración de sentidos y prácticas que garanticen el bien colectivo; por lo tanto la política en sí es creación. Esta creación se realiza a través de discursos y acciones colectivas que transforman los sistemas de valores y las prácticas sociales colectivas que afectan el bienestar individual y colectivo, impactando las maneras como las personas se relacionan entre sí y que logren cuestionar y transformar los ejercicios de poder que se dan en esta. (Alvarado y Ospina, 2014, p.44)

Es indispensable formar en subjetividades políticas, porque se requieren sujetos capaces de reconocer sus raíces, de trascender las fronteras del individualismo para dejar de ser solos en el mundo y anclar sus historias en redes complejas de intersubjetividades que les pongan en procesos de interdependencia con los otros. Con la configuración de las subjetividades estaríamos en el camino de una reactualización reflexiva del sentido de

6 Desde el punto de vista jurídico no es una ciudadanía plena porque hasta la mayoría de edad no se puede ejercer la totalidad de los derechos políticos. En tal sentido, sería más adecuado hablar de una ciudadanía restringida para los niños o adolecentes ya que, históricamente, la ciudadanía se manifiesta como una noción de naturaleza política más que social. 
lo político y de sus expresiones a partir de una redimensión de la RS que tienen las familias acerca de la participación política.

\section{ANÁLISIS E INTERPRETACIÓN DE LOS RESULTADOS}

Para el análisis de la categoría relacionada con las representaciones sociales acerca de la participación política, se trabajó con familias residentes en los estratos socioeconómicos: 1, 2, $3,4,5$ y 6 , con las cuales se desarrollaron entrevistas a profundidad $^{7}$ y se aplicó la técnica del dibujo creativo a los niños mayores de cinco años y a los adolescentes entre 14 y 17; para ambas técnicas se relacionaron las dimensiones de información, actitud y campo de representación como se observa en la Tabla 1; de igual manera emergieron otras categorías a lo largo del estudio que se tuvieron en cuenta para la interpretación de los resultados. Las dos técnicas anteriores y la observación permitieron adentrarse en el contexto de una manera activa, desarrollando anotaciones descriptivas de lo que se observó, siempre con el consentimiento de las personas protagonistas del estudio.

Para Hernández et al. (2014), la investigación cualitativa no es mera contemplación. Implica adentrarnos profundamente en situaciones sociales y mantener un papel activo, así como una reflexión permanente. Estar atento a los detalles, sucesos, eventos e interacciones. Las entrevistas son respondidas dentro de una conversación que se desarrolló con 11 familias, donde se utilizó un formato guía por formulaciones abiertas y la investigadora tuvo toda la flexibilidad para manejarla.

La entrevista cualitativa es más íntima, flexible, abierta; se conoce como una reunión para conversar e intercambiar información entre una persona y otra. En la entrevista, a través de las preguntas y respuestas, se logra una comunicación y construcción con-

7 Se aplicaron 23 entrevistas distribuidas en los seis estratos socioeconómicos. Se utiliza el siguiente nemotécnico: $\mathrm{E}_{\mathrm{i}} \mathrm{ES}_{\mathrm{j}} \cdot \mathrm{i}=$ Entrevista que va de la $23 ; \mathrm{j}=$ Estrato socioeconómico que va del 1 al 6 . 
junta de significados respecto a los temas que se están tratando.

Con relación a los niños mayores de cinco años y a los adolescentes, se les aplicó la técnica de las imágenes, quienes mediante un dibujo libre y creativo, plasmaron la representación social que tenían respecto al tema de estudio. Las imágenes ocupan, según Wagner et. al (2002) un espacio semántico propio, que puede ser lógicamente independiente de otras formas de saber. El método de comparación constante propuesto por Glaser y Strauss (1999) permitió hacer una interpretación de la representación social que tienen los miembros de la familia acerca del contexto sociopolítico y el proceso de socialización vivido al interior de la misma.

Las representaciones sociales tienen una función cognitiva y transformadora que no puede reducirse únicamente a la percepción, la memoria o las palabras, particularmente en niveles de interpretación. Siguiendo esta premisa, se pretende que la información que proporcionan los dibujos remitan a aspectos más primarios, previos a la palabra, en tanto que: "las imágenes vienen antes, las palabras luego, histórica y ontogenéticamente" (Mamali, 2006, p.31).

\section{ANÁLISIS E INTERPRETACIÓN DE LA CATEGORÍA REPRESENTACIONES SOCIALES (RS) ACERCA DE LA PARTICIPACIÓN POLÍTICA-SUBCATEGORÍA INFORMACIÓN (I)}

Al indagar a los distintos miembros de la familia con relación al conocimiento de la participación política subcategoría (I), se hallaron diferentes manifestaciones y se tomaron como ejemplo las siguientes:

- "Poco conozco la política que hace el gobierno" (E1Es1),

- "No conozco nada, no concuerdo con la política" (E5Es1),

- "No, participo mucho en política, relacionado con los partidos" (E6Es2), 
ESTUDIOS DOCTORALES FEMENINOS:

Aportes desde las Ciencias Sociales y Humanas

Tabla 1

Categorización de las representaciones sociales acerca de la participación política

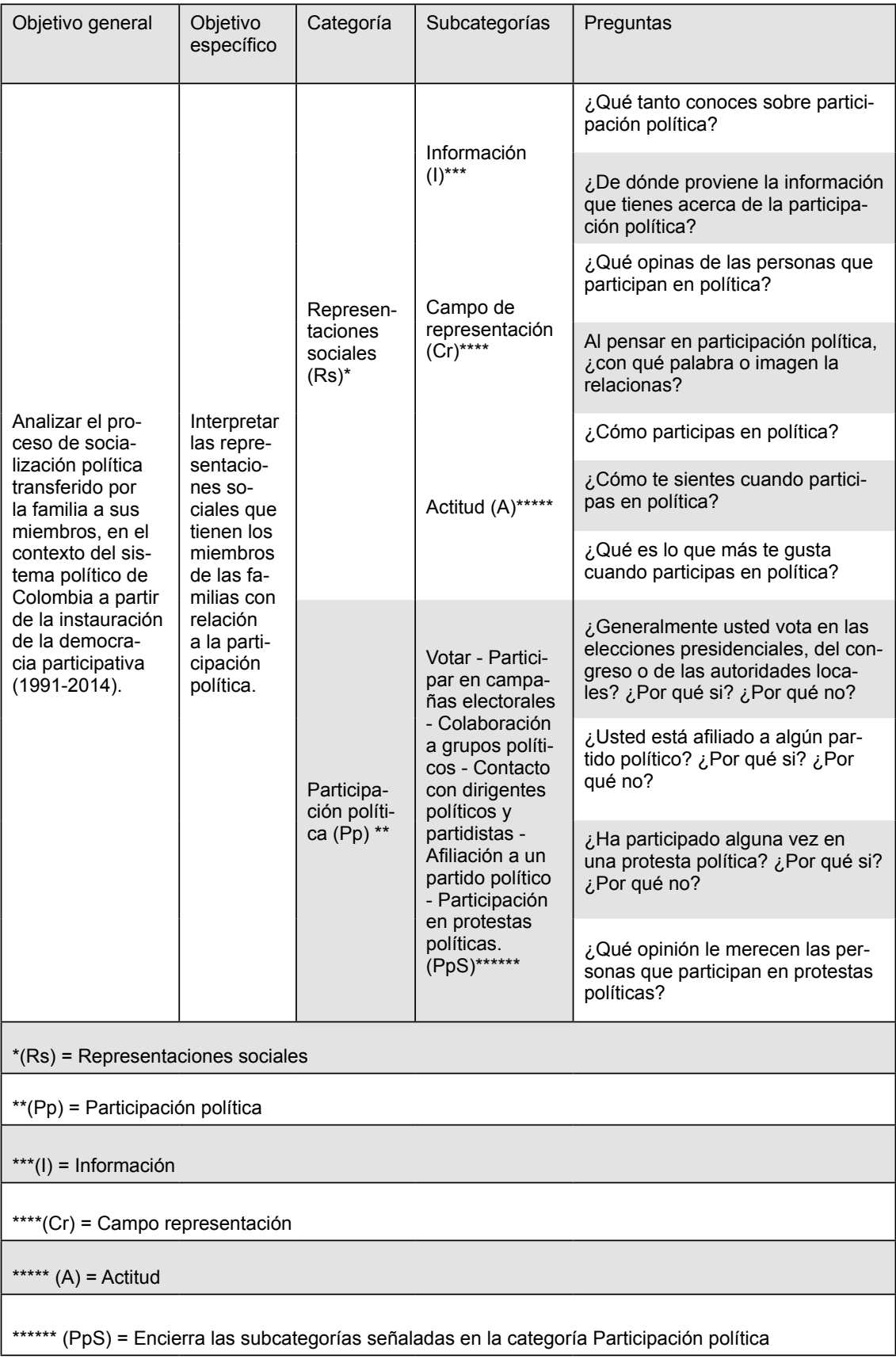

Fuente: Elaboración propia 
- "La verdad, no mucho, me imagino es la participación del ciudadano al momento de elegir un mandatario" (E11Es3),

- "Soy un poco apolítico, nunca me ha gustado participar, por eso no tengo un concepto claro" (E16Es4).

En su gran mayoría las familias entrevistadas expresaron tener poco conocimiento acerca de la participación política ${ }^{8}$, lo cual se vio reflejado al momento de definir el término, ya que consideran que esta hace referencia solo a los gobernantes y al hecho de emitir un voto.

Cabe destacar la posición adoptada por algunos entrevistados o entrevistadas, los cuales comentaron no saber nada acerca de la temática, situación que se convierte en un hallazgo importante que emergió como el analfabetismo político que tiene la población objeto y sujeto de estudio.

El peor analfabeto es el analfabeto político, él no ve, no participa de los acontecimientos políticos. El analfabeto político es tan ignorante que se enorgullece e hincha el pecho diciendo que no cree en ella y odia la política: no sabe que en su ignorancia política nace el menor abandonado, el asaltante, y el peor de los ladrones que es el político corrupto. (Tassara, 2005, p.105)

Lo anterior presupone que las circunstancias que generan la falta de información sobre la participación política, exponen a la población a un analfabetismo político y por ende convierten al ciudadano en un espectador de su suerte, dejando en muchas ocasiones a otras personas que decidan por él, ahondando ca-

8 La participación política implica a un conjunto de actividades que trascienden el acto electoral. En el marco de la llamada Democracia participativa y protagónica, la participación política se expresa en: contraloría social, parlamentarismo de calle, iniciativas de ley, referéndum en sus variadas modalidades, manifestación y marchas, militancia activa en organizaciones no gubernamentales, grupos de interés y partidos políticos, entre muchas otras. 
rencias y mala distribución de recursos; no obstante, es bueno mencionar también que personas y grupos sociales asumen la no participación política como parte de una estrategia política para desacreditar a un sistema político y económico que consideran injustos y opresivos, tal es el caso de los grupos irregulares, los abstencionistas y anarquistas, entre otros.

Con relación al sexo, los hombres mostraron mayor conocimiento en temas de participación política, ya sea porque les interesaba o porque factores externos como la socialización política, la identificación partidista, clientelismo, militancia en partidos políticos, factores de corto plazo en la toma de decisiones, entre otros, pudieron influenciar directamente en sus respuestas, o por el hecho de que por mucho tiempo la participación política fue monopolizada por los varones únicamente en el marco de un sistema patriarcal y clasista que relegaba a la mujer a una situación de inferioridad formal ante el sistema político y jurídico.

Parablemente, en su gran mayoría las mujeres respondieron no interesarles los temas políticos; tal situación pone de manifiesto dos elementos importantes: uno, la persistente discriminación hacia la mujer que se traslada hacia los asuntos públicos $\mathrm{y}$, otro, la profundización del sexismo y el machismo, que en definitiva sirven de explicación a la poca atención en los asuntos de la política por parte de la mujer, aún en el siglo XXI.

En Colombia, muy a pesar de los avances constitucionales y legislativos ${ }^{9}$ sobre la participación de la mujer, se superponen aún el atavismo cultural y valorativo que sobre este tema existe en la sociedad.

9 Véase los artículos 13, 40, 43 y 104 Constitución de 1991, la Ley Estatutaria 581 de 2000 o Ley de Cuotas, la Ley Estatutaria 1475 de 2011, la Ley 1434 de 2011, la Sentencia C-37 1 de 2000 y la Sentencia C-490 de 2011. 
Como se podría observar, las normas legales no necesariamente garantizan un real acceso a los espacios de decisión. Por tanto, los niveles de participación política de la mujer pasan por las relaciones de poder entre los hombres y mujeres, que se caracterizan por inequitativas para las mujeres. Así, nos basta, la igualdad ante la ley, pues existe una cultura sexista ${ }^{10}$ y androcéntrica"11. (Coronel y Sánchez, 2009, pp.77-78)

Por otro lado, hombres y mujeres de estratos socioeconómicos altos y con estudios universitarios tienen un conocimiento más cercano de lo que es participar en política. Se desprende, por consiguiente, que la condición socioeconómica de la población podría jugar un papel catalizador en la información que tienen los sujetos políticos sobre elementos esenciales en una democracia como lo es, la participación política y sus diversas manifestaciones.

El sistema político colombiano es para muchos investigadores abiertamente oligárquico, razón por la cual los pobres sienten que no les pertenece y no responde a sus necesidades y aspiraciones individuales y colectivas.

Las respuestas de los estratos socioeconómicos altos, distan de las de los estratos medios y bajos, lo cual podemos visualizar en estas respuestas:

- "Sabe uno que la participación política es el instrumento de la democracia que el país le brinda a los ciudadanos para

$10 \mathrm{El}$ sexismo imputa las diferencias históricamente instituidas a una naturaleza biológica que funciona como una esencia donde se deducen implacablemente todos los actos de la existencia. $Y$ entre todas las formas de esencialismo, el sexismo es sin duda el más difícil de desarraigar (De Barbieri, 1993, p.9).

11 Visión del mundo y de las relaciones sociales centrada en el punto de vista masculino. Diccionario de la Lengua Española. Edición del Tricentenario. En http://dle.rae.es/?id=2aQCw98. Recuperado el día 5 de abril de 2016. 
que puedan participar de manera activa y decisiva en las decisiones del país; en ese sentido la interpretación que tengo sobre participación política va dirigida a la posibilidad que tiene la gente de participar, de elegir, de ser elegido en el marco de una democracia institucional" (E20Es5).

- "Sobre participación política activa he tenido la oportunidad de estar pendiente de los procesos democráticos y participar en ellos siendo un líder político y reconocido aquí en mi barrio; siempre he tenido participación activa en los procesos electorales que se hacen en el municipio y que se hacen en Colombia" (E21Es5).

- "Bueno, participación política es la oportunidad que nos brinda la democracia para utilizar los diferentes mecanismos contemplados o no en la Constitución (E22Es5).

- “Cómo votar, estar en una liga de usuarios" (E23Es6).

Autores como Anduiza y Bosch (2015, p.188), señalan: "El hecho de que la posición social podría ser un indicador creíble de los valores políticos del ciudadano". Se desprende, entonces, que la posición social del ciudadano podría reflejar una desigualdad, tanto en la información como en la participación en política.

Por su parte Milbrath (1977, pp.92-106) concluía que: "Las personas de clase alta tienen mayor probabilidad de participar en política que las personas de clase baja... "Es casi universalmente cierto que las personas más prósperas, esto es, con mayores ingresos, tienen mayor probabilidad de participar en política que las menos prósperas".

Ahondando sobre (I), se precisó ¿De dónde proviene la información que tiene acerca de la participación política? 
Para analizar RSI se seleccionaron algunos registros que dan cuenta de la influencia de los agentes de socialización en las RS de la participación política.

- "Vida cotidiana, familia, radio" (E3Es1).

- "Medios de comunicación" (prensa y radio). (E4Es1).

- "Medios de comunicación" (E7Es2).

- "Padres- Ancestro" (E8Es2).

- "Televisión, periódico y radio" (E13Es3).

- "No tengo información" (E16Es4).

- "Medios de comunicación" (E17Es4).

- "Como líder comunitario, como líder social he tenido la oportunidad de obligatorio cumplimiento para todas aquellas personas que nos vamos por el carácter social de ayudar siempre a la sociedad, estar escudriñando para tener conocimiento de todos los políticos que se mueven en todas las actividades que deben ser y, cuando hablamos de participación política hay que tener todo el conocimiento de cómo se participa en política" (E21Es5).

- "Bueno yo lo dividiría en dos partes, primero en mi niñez, mi familia influyó porque afortunadamente tuve el privilegio de conocer todo lo relacionado con el tema porque mi padre fue un líder político en el municipio donde vivo y, posteriormente, esas inquietudes que él nos fue sembrando se fueron desarrollando en mis estudios profesionales; ahorita mismo soy abogada, me especialicé en Derechos Humanos y Derecho Penal y he tenido la oportunidad de participar en muchas actividades políticas" (E22Es5).

- "Del estudio que he hecho de la Constitución, de las lecturas y de la práctica misma" (E23Es6).

Las familias, en líneas generales, consideran que la información referente a la participación política la han obtenido a través 
de los medios de comunicación, y un pequeño grupo considera a la familia como agente socializador.

El estrato socioeconómico estableció diferencias en términos de conocimiento y participación en política, siendo significativos los estratos cuatro, cinco y seis, los cuales respondieron tener información sobre el tema, asegurando que se dio en algún momento un proceso de socialización política al interior de la familia sin desconocer que otros factores secundarios de socialización política han podido influenciar a lo largo de sus vidas.

En este orden de ideas, Festinger (1962) asegura que los valores políticos son el principal instrumento mental que utilizan los ciudadanos al procesar información política que interceptan. Una vez reciben la información que encierra un contenido político, muy pocas veces la evalúan de manera lógica; es extraño que las personas se dediquen a reunir todos los datos que permitan hacer una idea objetiva de los hechos y a calcular si estas consecuencias están en desacuerdo con nuestra noción de lo que está bien y lo que está mal. En general, el individuo compara la información que le llega con un valor político que tiene interiorizado, intuye si le cuadra o no con este valor político y adopta una postura de aceptación o rechazo de esta información. Por ello Anduiza y Bosch (2015, p.191) explican:

La socialización política permite consolidar los valores explícitamente políticos del ciudadano. Hay diferentes agentes de socialización con un papel destacado en la socialización política. Estos agentes son los instrumentos, los medios a través de los cuales se transmiten los valores políticos al individuo. 


\section{ANÁLISIS E INTERPRETACIÓN DE LA CATEGORÍA REPRESENTACIONES SOCIALES (RS) ACERCA DE LA PARTICIPACIÓN POLÍTICA-SUBCATEGORÍA CAMPO DE REPRESENTACIÓN (CR)}

Al indagar a los distintos miembros de la familia con relación al conocimiento de la participación política, sub categoría (CR) se hallaron diferentes manifestaciones y se tomaron como ejemplo las siguientes:

- "Algunos realmente ejercen la función, pero la gran mayoría lo hace para satisfacer sus propias necesidades" (E2Es1).

- "Son iguales, nunca creo en ellos" (E5Es1).

- "Personas que nacen con ese don y otras que buscan lucrarse" (E8Es2).

- "Buscan poder" (E9Es2).

- "Son personas vinculadas a esto para lograr cambios y otras por motivos personales" (E11Es3).

- "No los califico; me intereso poco por eso" (E12Es3).

- "Si se trata de los gobernantes, lo que buscan es su propio beneficio, es un círculo, el cual está regido por una persona" (E14Es4).

- "Son personas consientes de la importancia que poseen para el desarrollo de una sociedad igualitaria" (E19Es4).

- "Que su papel es importante, que se involucran en las decisiones, que hacen valer su decisión ante el país ante las entidades territoriales a las que asisten; son importantes para la democracia porque el insumo básico y fundamental de la democracia es la gente, que la gente participe, que la gente entienda que tiene derecho de elegir, de ser elegido, que sus voces son importantes para tomar decisiones frente a una cosa puntal que afecte o no al ciudadano" (E20Es5).

- "Bueno, me parecen bien, porque no le dejan su suerte a otro. Luchan por ellos y la comunidad" (E23Es6). 
Para los estratos uno, dos y tres existe un consenso por parte de las familias al considerar que son los políticos las personas que participan y que estos buscan defender sus propios intereses; sin embargo para los estratos cuatro, cinco y seis la participación en política ha sido en doble vía, de tal manera que reconocen la participación de los políticos y la de ellos dentro del proceso de una manera activa.

Cuando las familias piensan en política se les vienen imágenes tales como:

- "Políticos" (E1Es1).

- "Voto" (E3Es1).

- "Alcaldía, presidencia, mandato" (E8Es2).

- "Político" (E9Es2).

- "Elecciones" (E11Es3).

- "Apoyar un político" (E12Es3).

- "Líderes políticos" (E14Es4).

- "No le paro bola a eso, la verdad" (E15Es4).

- "Negocio" (E16Es4).

- "Con democracia, con el conglomerado social que tiene la oportunidad de poder hacer mostrar sus intereses a través de los medios masivos que permiten la democracia" (E21Es5).

- "Con inclusión, con grupos sociales, con jóvenes, niños, con comunidad y respeto" (E22Es5).

- "Con poder, servicio al otro. Aunque en Colombia muchos la asocian con corrupción" (E23Es6).

Las familias relacionan la política con los líderes y candidatos políticos, votos, corrupción, dinero y elecciones y un pequeño número lo relaciona con democracia, participación y esperanza, a que se cumpla lo prometido en las campañas electorales y los respectivos programas de gobierno de los líderes que logran ac- 
ceder a los espacios de poder. En todo caso la teoría a nuestra disposición sobre participación política se ve reflejada, de una manera u otra, en los casos estudiados, por cuanto:

La participación política adopta formas muy variadas, desde la emisión del voto, hasta la protesta política más radical (...) el estatus social, la edad o la pertenencia a asociaciones proporcionan recursos y habilidades cívicas que favorecen la participación. Las actitudes de interés por la política, la politización y el grado de satisfacción o frustración también pueden incidir sobre la participación. (Anduiza y Bosch, 2015, p.60)

\section{ANÁLISIS E INTERPRETACIÓN DE LA CATEGORÍA REPRESENTACIONES SOCIALES (RS) ACERCA DE LA PARTICIPACIÓN POLÍTICA-SUBCATEGORÍA ACTITUD (A)}

Al indagar a los distintos miembros de la familia con relación al conocimiento de la participación política, subcategoría $(A)$, se hallaron diferentes manifestaciones y se tomaron como ejemplo las siguientes:

- "Votando" (E2Es1).

- "A través de ir temprano a votar" (E4Es1).

- "De ninguna forma" (E5Es1).

- "Ejerciendo derecho al voto" (E8Es2).

- "Ayudando a buscar votos" (E9Es2).

- "Muy poco participo, si de pronto un político me invita" (E10Es3).

- "Nada más voto" (E12Es3).

- "Nada más voto" (E15Es4).

- "Nada más voto" (E17Es4).

- "Diferentes mecanismos de participación ciudadana" (E19Es4).

- "La participación que yo personalmente he tenido en política ha sido a través de los escenarios de brindar mi voto de 
confianza e, inclusive también he tenido la oportunidad de presentar mi nombre en cargos concretos; en ese sentido puedo decir que he tenido esa oportunidad de hacer valer el derecho propio de poder elegir pero también a ser elegido" (E20Es5).

- "Cuando joven participaba en marchas, protestas, hoy me limito al voto" (E23Es6).

Las familias consideran, a grandes rasgos, que la forma como se participa en la política es a través del voto, desconociendo las otras formas de participación política; algunos manifestaron que no participan. Al explicitar cómo se sienten cuando participan en política, los entrevistados respondieron:

- "Poco participo, pero cuando lo hago me siento bien" (E1Es1).

- "Bien" (E4Es1).

- "Limpia, no acepto dinero ni vendo mi conciencia" (E8Es2).

- "Es un deber participar y votar, me siento satisfecho" (E9Es2).

- "Bien, porque cumplo con mi derecho, lo que me da la oportunidad de opinar" (E11Es3).

- "Me gusta colaborar por el ejercicio del voto" (E12Es3).

- "No participo, no me gusta porque no puedo hacer nada para cambiar" (E14Es4).

- "Muy mal porque los dirigentes manejan muy mal la política" (E16Es4).

- "Comprometido por un interés general y buscando siempre un beneficio a través de la participación democrática a la comunidad a la cual me presento" (E21Es5).

- "Me siento bien, aunque a veces uno se desencanta por la ejecutoria de los gobernantes o porque el candidato por el que voté no fue elegido" (E23Es6). 
Los que han participado en política manifiestan sentirse bien al momento de hacerlo, debido a que cumplen con un deber y derecho como ciudadano. Otros miembros de la familia dicen participar para que su candidato gane y cumpla las promesas y para ejercer la democracia mediante el voto.

Al preguntarles: ¿Qué es lo que más te gusta cuando participas en política?, respondieron de la siguiente manera:

- "La idea es que cumpla sus promesas" (E2Es1).

- "La persona que califique sea escogida" (E3Es1).

- "Nada" (E5Es1).

- "Que gane el candidato porque voté" (E6Es2).

- "Que no nos engañe" (E9Es2).

- "Que el candidato por el que apoyo gane" (E12Es3).

- "Que gane por el que voté y haga las cosas bien" (E13Es3).

- "Nada, no me gusta" (E14Es4).

- "Que gane un candidato con compromiso" (E18Es4).

- "Poder exigir que se cumpla lo que contemplan los planes de gobiernos y leyes" (E19Es4).

- "El hecho de que decisiones trascendentales estén sujetas a la voluntad del pueblo independientemente si la mayoría se equivoca o no, lo importante es que existe un sistema democrático, con unas garantías específicas que le brindan la oportunidad al ciudadano de sentir que su voz y su voto tienen validez al momento de la toma de decisiones" (E20Es5).

- "Conocer las comunidades, la gente, tratar con las personas, saber qué necesidades básicas tienen, qué expectativas tienen con las personas que se postulan para ser elegidas, sobre todo me gusta lo que tiene que ver con las personas y la comunidad" (E22Es5).

- "Me gusta seguir los debates, las encuestas, las noticias e ir a votar con mi familia" (E23Es6). 
Las familias relacionan estas respuestas con los compromisos que adquirieron los líderes políticos en su programa de gobierno o propuestas legislativas. Otros manifestaron interés por los debates políticos y algunos siguen las encuestas; estos últimos, por lo general se inclinan por el que mejor le vaya en las encuestas con el propósito de no perder o sentirse perdedor en las elecciones. Como se puede observar priman sobre todos los factores a corto plazo al momento de decidir por quién votar.

Downs (1957), en su libro An Economic Theory of Democracy precisa que la decisión del ciudadano se sustenta en la percepción que tiene acerca de los candidatos que compiten en una elección, en la evaluación que se haga respecto a su desempeño en el pasado, o el beneficio que se pueda obtener acerca de las promesas futuras.

\section{ANÁLISIS E INTERPRETACIÓN DE LA CATEGORÍA PARTICIPACIÓN POLÍTICA (Pp) ${ }^{\mathbf{1 2}}$}

Ante esta categoría participación política $(P p)$ se observan las siguientes respuestas:

- "Sí, es mi deber como ciudadana" (E1Es1).

- "Sí, porque soy buena ciudadana" (E4Es1).

- "Sí, un voto hace la diferencia" (E7Es2).

- "Sí, desde que cumplí 18 años no lo he dejado de hacer" (E8Es2).

- "Sí, para ver si sacan adelante la situación actual" (E10Es3).

- "Deber ciudadano" (E13Es3).

- "Presidenciales nunca. Concejo y cámara sí, como eso pagan por el voto" (E15Es4).

- "Sí, por compromiso hacia la sociedad y para un mejor futuro" (E18Es4).

12 Incluye como subcategoría, cómo votar, participar en campañas electorales, colaboración con grupos políticos, contacto con dirigentes políticos y partidistas, afiliación a un partido político, participación en protestas políticas. 
- "Sí, he votado para las elecciones presidenciales, congreso en cámara, en cada una de esas he participado; también he participado; con mi decisión libre de apoyar o respaldar algún nombre en concreto" (E20Es5).

- "Siempre que hay una elección popular en mi país lo he hecho y siempre lo voy a hacer porque considero que cuando nosotros votamos tenemos el derecho a saber si ese voto fue importante o no fue importante y, siempre que hay elecciones lo hago porque es mi derecho como ciudadano" (E22Es5).

- "Sí voto en todas. Pero voto por simpatía con los candidatos no por partidos. Además generalmente voto en blanco en alguna corporación. En la última elección a alcalde voté en blanco" (E23Es5).

Algunas familias, específicamente de los estratos tres, cuatro, cinco y seis manifiestan haber participado en diferentes actividades políticas, tales como marchas, elecciones y postulaciones, asegurando que han participado en política, pero no pertenecen a ningún partido político en concreto.

Ante la pregunta sobre si está afiliado en algún partido político ¿Por qué sí? ¿Por qué no?, responden con las siguientes expresiones:

- "No, con tanto partido que existe" (E2Es1).

- "No, nunca me ha gustado" (E5Es1).

- "No me gusta" (E6Es2).

- "No, pero tengo familia vinculada a partidos y los apoyo" (E9Es2).

- "No, no me interesa, todos tienen buenas propuestas, lo que brinda la posibilidad de variar" (E11Es3).

- "Ninguno, no soy ni azul ni rojo" (E12Es3). 
- "No, no me gusta mezclarme" (E14Es4).

- “Ninguno, no me llama la atención" (E16Es4).

- "No he tenido nunca afiliación o disciplina con partidos en concreto, sí he sostenido y construido relaciones de cercanía política con políticos que sí hacen parte de algunas tendencias ideológicas muy concretas, del partido liberal, del partido conservador; yo pudiera decir que no he estado encasillado, ni he estado limitado, yo creo más en los individuos, en los proyectos, en las propuestas programáticas que deben estar por encima de los partidos, igual los respeto y creo que son importantes en una democracia" (E20Es5).

- "De afiliación de partido político, no pertenezco a ningún partido; mis inclinaciones políticas tienen tendencias al socialismo y aquí en nuestro país eso no es mirado con buenos ojos, en primera instancia. Pero mi tendencia política se inclina para la parte social, no va para el centro ni para la derecha" (E21Es5).

- "No estoy afiliado a ningún partido político. En Colombia no hay tradición de afiliarse políticamente a ningún partido. Tú votas por simpatías, por favores, por clientelismo" (E23Es6).

Con relación a la participación política, las familias tienen una apreciación relacionada con el deber de ejercer la democracia mediante el voto, no les atrae pertenecer a ningún partido político porque no les generan confianza y, los que lo hacen, están guiados, en la mayoría de los casos estudiados, por el clientelismo en la búsqueda de un beneficio personal. Según Torcal (2003) esta situación se explica porque en la actualidad se detecta un descenso en el grado de confianza en las instituciones políticas, el apoyo al gobierno, y muy especialmente en la valoración de partidos políticos. 
Cuando se les consultó sobre su participación en alguna protesta política: ¿Por qué sí? ¿Por qué no? Algunos respondieron así:

- "No, nunca me ha llamado la atención" (E1Es1).

- "Sí, por convicción, una vez en Venezuela" (E3Es1).

- "No me gusta involucrarme" (E5Es2).

- "No me gusta" (E7Es2).

- "No me parece, es cuestión de buscar la paz" (E10Es3).

- "No, nunca me ha llamado la atención" (E12Es3).

- "No participo, no me gusta porque no puedo hacer nada para cambiar" (E14Es4).

- "Cuando estaba joven me motivaba, era algo personal" (E16Es4).

- "Sí he participado, participé como estudiante universitario en varias oportunidades cuando estuvimos en desacuerdo con la reforma de la Ley de la Educación superior, que rige a las Instituciones de Educación Superior aquí en Colombia. Participé en propuestas ciudadanas por prestaciones de malos servicios públicos en el caso del municipio de Soledad y, participaciones de protesta o rechazo ciudadano frente a situaciones de violencia" (E20Es5).

- "Desde el inicio del bachillerato participaba en protestas estudiantiles, fui representante estudiantil del colegio INEM del municipio de Soledad y hacíamos actividades, marchas pacificas que tenían como objeto poder conseguir el bien de toda la comunidad Inemita en su momento. Después, en el mismo barrio hacíamos propuestas para conseguir aquellas cosas que se nos fueron negadas, un ejemplo grande de eso fue que hicimos una propuesta porque no teníamos parque y pudimos hacer que el gobernador llegara al parque Muvdi; le hablo del año 1992 y conseguimos que nos crearan el parque Muvdi que hoy en día volvió a ser renovado" (E21Es5). 
- "Sí, participé cuando era estudiante de bachillerato y en la universidad cuando los partidos de izquierda motivaban a los jóvenes a protestar. Ahora como adulto marché por la paz de este país" (E23Es6).

Los efectos de la protesta política y de la participación no convencional son más controvertidos. Para algunos, un cierto grado de apatía es saludable para la democracia, ya que reduce las demandas transmitidas al sistema. El aumento de la participación no convencional fue percibido en su momento como una amenaza a la democracia representativa, tal como explican Anduiza y Bosch (2015).

Con relación a la apreciación que tienen sobre las personas que participan en protestas políticas, expresaron lo siguiente:

- "Que son personas que apoyan a un partido y por eso pelean" (E2Es1).

- "Bien, porque la política mueve" (E3Es1).

- "No, esto conlleva a pelea" (E4Es2).

- "Estoy de acuerdo, pero que siempre lo hagan pacíficamente" (E8Es2).

- "No me parece que estén actuando bien" (E10Es3).

- "Cuando hay necesidad es bueno que lo hagan" (E13Es3).

- "No tengo un calificativo, son personas sin claridad en sus ofrecimientos" (E16Es3).

- "Es correcto para que no se les vulneren y restituyan sus derechos" (E19Es4).

- "Que tienen sus intereses, sus opiniones y eso le hace bien a la democracia. La protesta es un derecho, lo que pasa es que en Colombia todo se resuelve a bala" (E23Es6).

La participación en protestas políticas en algunas familias se 
responde con un NO rotundo, puesto que lo ven como un acto indebido en el ámbito político y social, mientras que las familias de los estratos socioeconómicos más altos, coinciden en que la protesta le hace bien a la democracia.

En tal sentido Parryy, Moyser y Day (1992) en su estudio sobre participación política, concluyen que no se produce un incremento en la percepción del nivel de conocimiento político de los participantes. Solo los que han trabajado en campañas y en el interior de partidos políticos reconocen que han aprendido. Sin embargo, son datos que se basan en la percepción de los propios individuos, que como sabemos no son buenos jueces de sí mismos. Este efecto educativo de la participación se concentra, además, entre los ciudadanos más participativos y con recursos disponibles.

Representación social acerca de la participación política aplicada a niños y adolescentes mediante la técnica del dibujo creativo

En la aplicación de la técnica del dibujo, se presentan seis ilustraciones elaboradas por niños y adolescentes de los diferentes estratos socioeconómicos de Barranquilla, a los cuales se les brindó la oportunidad de elaborar un dibujo entregándoles unas hojas y colores para que plasmaran, de forma libre y creativa, las representaciones que tienen acerca de la participación política. Fue un ejercicio donde participaron desprevenidos y sin presión por parte de la investigadora. 


\section{Ilustración 1}

Representación social acerca de la participación política en adolescente de 15 años de estrato 4
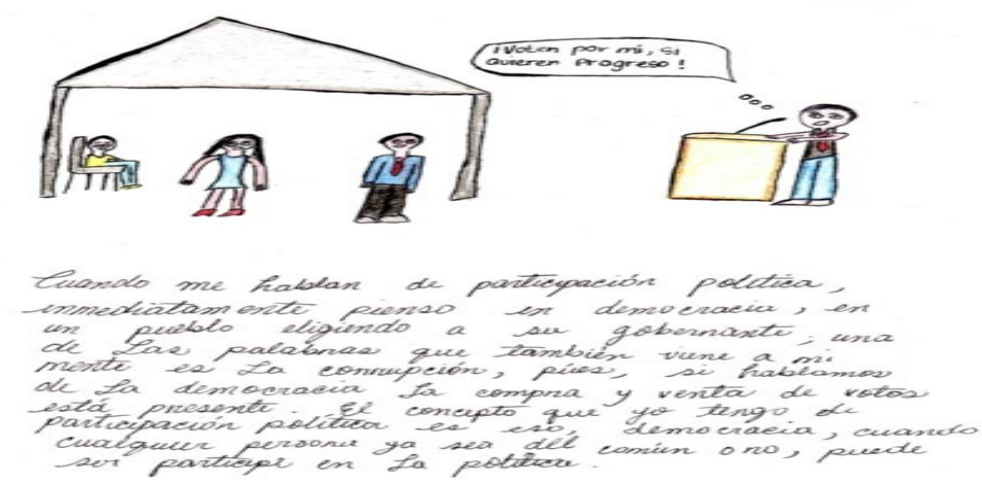

Fuente: Anexo 4. Técnica de dibujo aplicada a familia No. 8

¿Qué interpretación se le da a la ilustración 1?

La lectura hermenéutica del dibujo muestra en sus imágenes, elementos de la participación política, específicamente, la participación en campañas electorales donde el candidato está presentando su programa de gobierno a los espectadores, que son las personas que contemplan la política desde las barreras, pero que también pueden participar esporádicamente. En esta representación hay presencia de los factores a corto plazo que inciden en la decisión del voto como son las campañas electorales y programas de gobierno. Otros aspectos que señala están relacionados con la democracia mediante el ejercicio del voto y la corrupción.

Los factores a corto plazo referidos a la campaña electoral misma son: la imagen de los candidatos y la evaluación que sobre ellos hacen los electores, su experiencia en gobernar o en otros ámbitos no políticos. Sus cualidades o defectos, son los temas más relevantes durante la campaña electoral, o los que tienen mayor acogida o significación o que causan impacto. (Morales, 2015, p.102) 


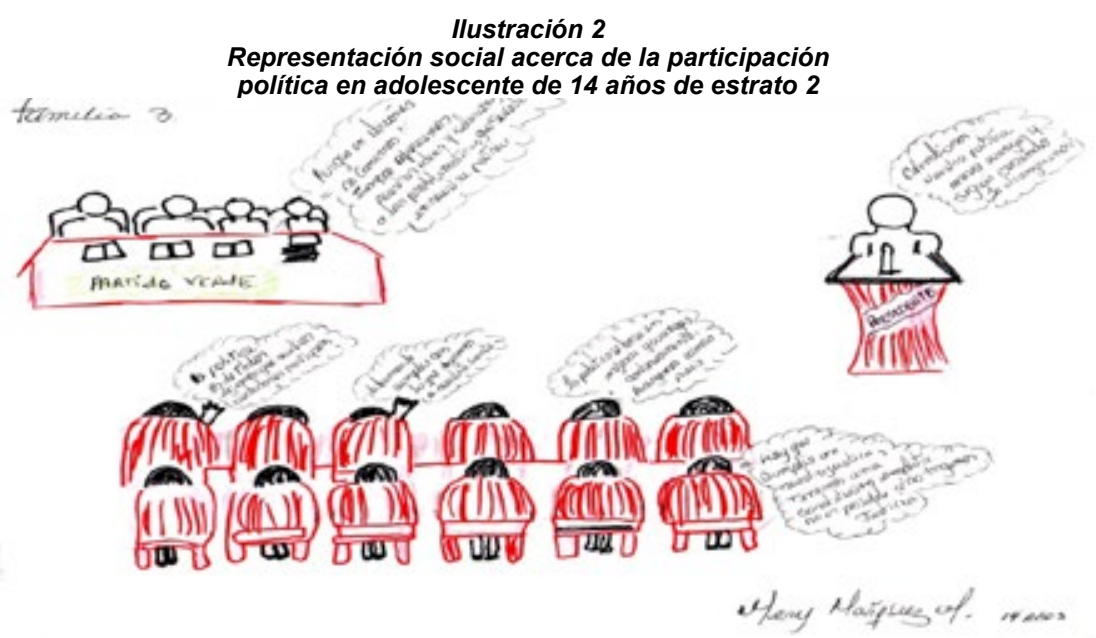

Fuente: Anexo 5. Técnica de dibujo aplicada a familia No. 3

¿Qué interpretación se le da a la ilustración 2?

Se devela mediante la descripción de los textos que acompañan los dibujos, categorías como democracia, mejoras para el país, justicia por el incumplimiento de las promesas y corrupción por la compra y venta de votos y, la inclinación hacia el partido de preferencia; o puede ser por identificación partidista de la familia o por otro agente de socialización que ha influido en el desarrollo de las preferencias políticas. Para revelar esta realidad Eastman (1996) plantea que el punto de encuentro entre la democracia y la corrupción es la gobernabilidad, dando a entender con ello la importancia de la movilización pública, desde luego a partir de la búsqueda continua de una mejor distribución de los diversos recursos públicos y con ello, a una clara y concreta rendición de cuentas sobre su administración. 


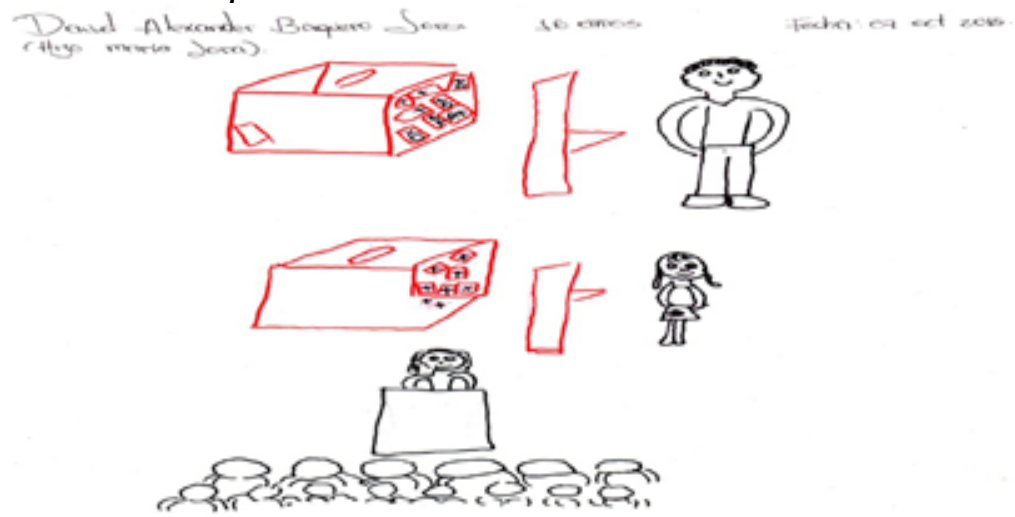

Fuente: Anexo 6. Técnica de dibujo aplicada a familia No. 2

¿Qué interpretación se le da a la ilustración 3?

Los dibujos están relacionados de igual manera con la participación en las campañas políticas e incluye otro elemento de participación política como es el voto, el cual es reconocido por las familias que formaron parte de este estudio como un elemento de participación política bien interiorizado, independientemente que sea democrático o no. Este acto de participación electoral pudo haber sido socializado al interior de la familia o, por eventos políticos más frecuentes vistos por los ciudadanos y percibidos desde la niñez por otros agentes secundarios de socialización política, que le permitieron ir construyendo representaciones sociales relacionadas con la participación política y se refleja en este dibujo en concreto. Para Anduiza y Bosch $(2015$, p.28) la participación electoral es una forma de participación esencial y perfectamente integrada en la estructura institucional de la democracia representativa. Con frecuencia, en sentido estricto, el término 'participación electoral' se utiliza como sinónimo de votar. 


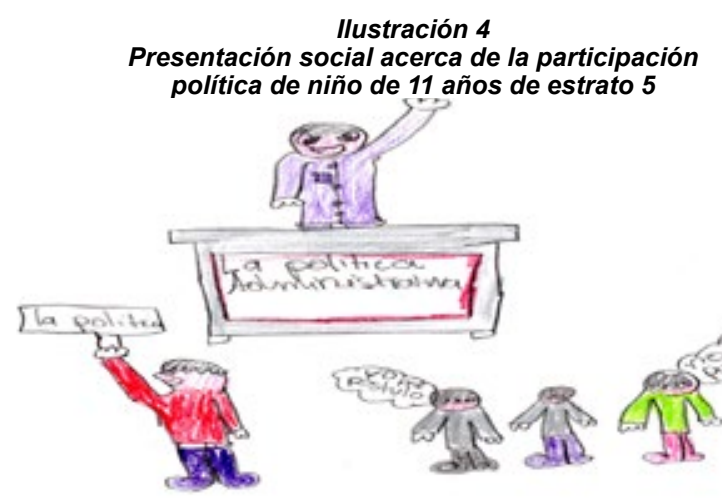

Fuente: Anexo 7. Técnica de dibujo aplicada a familia No. 9

¿Qué interpretación se le da a la ilustración 4?

La figura da muestra de una representación social de la participación política un tanto heterogénea porque comprende varios elementos como es, la postulación a un cargo público, liderazgo desde el gobierno y rechazo hacia la manera como se están operando las políticas públicas, también se percibe el deseo de que haya un cambio en el gobierno o en sus estrategias de desarrollo. En este sentido:

Podríamos definir la participación política como cualquier acción de los ciudadanos dirigida a influir en el proceso político y en sus resultados. Estas acciones pueden orientarse a la elección de los cargos públicos; a la formulación, elaboración y aplicación de las políticas públicas que estos llevan a cabo o a la acción de otros actores políticos relevantes. (Anduiza y Bosch, 2015, p.26) 


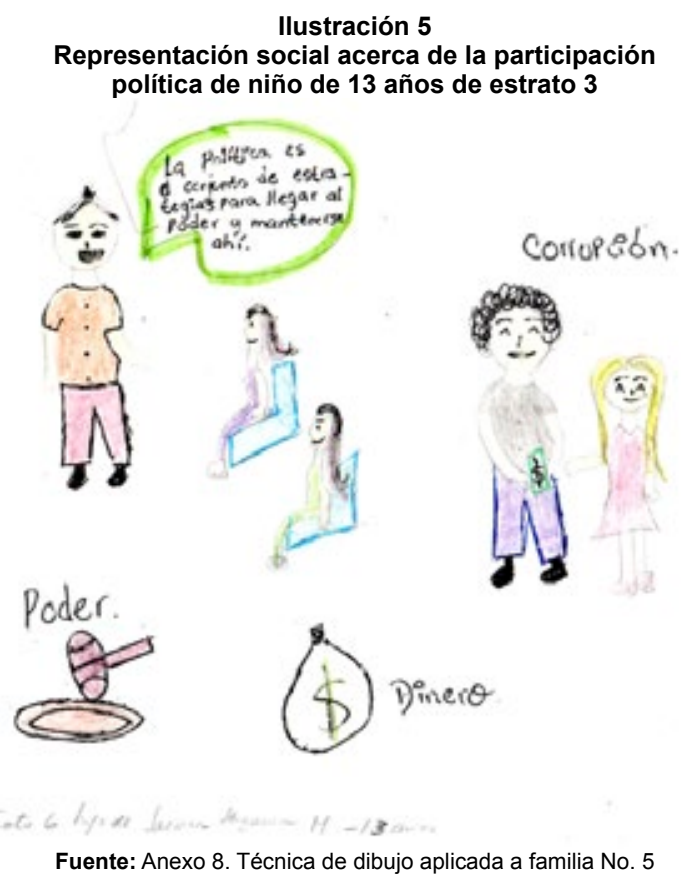

¿Qué interpretación se le da a la ilustración 5?

Este dibujo se orienta hacia una representación social de la participación política muy marcada por la idea de la corrupción, clientelismo, el poder y la influencia de los partidos políticos en la decisión del voto. Arriagada (2013, p.2) expresa que:

"Muchos autores plantean que las personas deciden participar en un vínculo clientelar, motivados por el interés de satisfacción de sus necesidades. Desde esta perspectiva, el clientelismo sería una relación de intercambio voluntaria entre actores que buscan obtener ventajas de la relación, por tanto estaría marcada por una lógica económica, donde se transan bienes o servicios inmediatos por apoyo político o votos".

Sin, embargo Auyero (1998), que es uno de los principales estudiosos del fenómeno en los últimos años en Chile, critica el supuesto que se encuentra detrás de la noción de clientelismo 
como un simple intercambio de favores por votos, ya que las relaciones clientelares pueden ser mucho más complejas y terminar desembocando, incluso, en la estructuración de vínculos afectivos, irracionales desde la perspectiva de la lógica económica, por cuanto la persona y los grupos terminan perdiendo mucho más de lo que reciben, tal como lo demostraría cualquier evaluación costo-beneficio, en el mediano y largo plazo.

En Colombia estas actividades pueden ser un caldo de cultivo muy fértil para prácticas que rayan en la ilegalidad, como son los actos de corrupción.

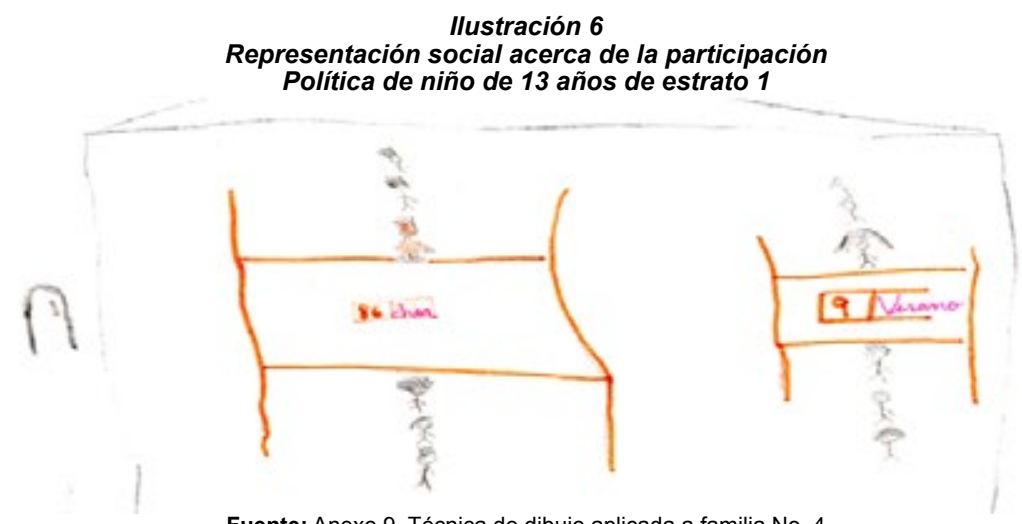

Fuente: Anexo 9. Técnica de dibujo aplicada a familia No. 4

¿Qué interpretación se le da a la ilustración 6?

El trabajo hermenéutico de este dibujo muestra la relación de la participación política también referida con el voto y la identificación de dos líderes políticos del departamento, un personaje que se postuló como alcalde y el otro como gobernador respectivamente. Los dos trabajaron aliados políticamente y resultaron elegidos. Aquí priman también los factores a corto plazo que hacen efecto en el nivel de recordación producto de las campañas políticas al momento de decidir por quién votar, como lo dice la autora en la cita anterior. 
Las RS acerca de la participación política que muestra este estudio, emergen como un fenómeno inserto en tejido social. Es importante destacar que, a través de la acción de los sujetos sociales actuando en el espacio común de la esfera pública y privada, pueden elaborar y fijar sus representaciones sociales.

Se pudo considerar la información aportada por las personas participantes, como una lectura o una interpretación sobre la realidad que intentan comprender. Sin duda, el acto de interpretación de la realidad se da en aquellos procesos de comunicación e interrelación asentada en la mediación entre un discurso construido de modo colectivo que acaba generando RS.

\section{CONCLUSIONES}

Con base en las apreciaciones conceptuales y teóricas expuestas en este capítulo producto de la investigación, se infiere varios son los aspectos que se integran en un proceso de participación política, donde el eje central es el ciudadano y la comunidad, lo cual conlleva a la necesidad de socializar todas aquellas actividades que estimulan una actitud de participación política que conduzca a empoderarse y movilizarse, si es el caso.

La información aportada por las familias participantes permite hacer una lectura o una interpretación sobre la realidad que intentan comprender. Sin duda, el acto de interpretación de la realidad se da en aquellos procesos de comunicación e interrelación asentada en la mediación entre un discurso construido de modo colectivo que acaba generando RS con fuerte incidencia en el sistema político en general, ya que de esas RS emergen en el tiempo y espacios identidades políticas y prácticas que sirven, por una parte, para sostener el orden establecido y, por otra, para transformarlo; de ahí su dialecticidad. 
El estudio estuvo mediado por la forma en que las familias concibieron la participación política y la influencia de los agentes de socialización como: la familia misma, los grupos de pares, los medios de comunicación y los partidos políticos.

En los estratos 1 y 2 se observó que en los adultos, sus familias de origen poco desarrollaron en ellos un proceso de socialización política y, los que lo hicieron, no fue bajo los principios de la democracia, de tal manera que la socialización se dio por otros agentes secundarios.

Los niños y adolescentes, mediante los dibujos, mostraron una representación social acerca de la participación política, producto de las imágenes, símbolos e imaginarios que han ido construyendo en el marco de la familia y del entorno en el que se mueven como actores sociales y sujetos políticos en desarrollo.

Las familias -en su mayoría- relacionan la participación política con el voto en una clara concepción reduccionista de este concepto.

Por su parte, el tema de la corrupción y el clientelismo estuvo presente, afectando negativamente la visión de democracia y atentando contra el equilibrio de los poderes. Por todo esto la democracia sufre un estancamiento porque se debilita y se destruye con la corrupción administrativa del aparato de gobierno en todos sus niveles.

En la medida en que el ciudadano conozca todas las actividades, formas y mecanismos de participación política y las interioricen, hay la probabilidad de que se asuman por parte de la comunidad y se generen nuevas representaciones sociales acerca de la participación política, en búsqueda de una demo- 
cracia sustantiva; es decir, que no solo se exprese como forma de Estado y de Gobierno, sino como cultura política generalizada y modo de vida.

\section{REFERENCIAS BIBLIOGRÁFICAS}

Abric, J. (2001). Las representaciones sociales: aspectos teóricos (Primera edición). En Prácticas sociales y representaciones. México: Ediciones Coyoacán.

Alvarado y Ospina (2014). Socialización política y configuración de subjetividades. Construcción social de niños, niñas, y jóvenes como sujetos políticos. Bogotá: Manizales Universidad de Manizales; Sabaneta: Siglo de Hombres Editores.

Anduiza, E. y Bosch, A. (2015). Comportamiento Político y Electoral (Segunda impresión). Barcelona, España: Editorial Ariel.

Auyero, J. (1998). Todo por amor, o lo que quedó de la herejía. Clientelismo populista en la Argentina de los noventa. En El fantasma del populismo. Aproximación a un tema (siempre) actual. Caracas, Venezuela, Burbano de Lara, Felipe (Ed.). Caracas: Editorial Nueva Sociedad.

Castorina, A. (2003). Representaciones sociales. Problemas teóricos y conocimientos infantiles: de las representaciones colectivas a las representaciones sociales. Ida y vuelta. Barcelona, España: Gedisa.

Coronel, E. y Sánchez, R. (2009). Mujeres en el municipio: participación política de concejalas de Cochabamba. (Primera edición). La Paz: Universidad Mayor de San Simón.

De Barbieri, T. (1993). Sobre la categoría género. Una introducción teórico-metodológica, Debates en Sociología, 18. Lima: Pontificia Universidad Católica del Perú.

Downs, A. (1957). An Economic Theory of Democracy. New York: Harper Collins. En español: Teoría económica de la democracia. Madrid: Ed. Aguilar, 1973.

Durkheim, E. (1898). Représentations individuelles et représen- 
tations collectives. Revue de Métaphysique et de Morales. VI, pp.273-300.

Durkheim,E. (2000). Representaciones individuales y representaciones colectivas. En Sociología y filosofía, pp. 27-58. Madrid: Miño y Dávila Ediciones .

Eastman, J. (1996). Descentralización y Corrupción: el problema de la Gobernabilidad. En Descentralización y Corrupción, Bogotá: Fescol-Milenio, Espinel Vallejo, Manuel (Compilador). (2002), p.25.

Farr, R. (1984). Social representations: Their role in the design and execution of laboratory experiments. New York: Editions de la Paris

Festinger, L. (1962). A Theory of Cognitive Dissonance. Primera reimpresión. USA: Stamford University Press.

Festinger, L. (1975). A Theory of Cognitive Dissonance. Stanford: Stanford University Press.

Franco, B. y Flórez, J. (2009). Aproximación teórico-conceptual de la participación electoral, una discusión aún abierta. $R e-$ vista Desafíos, (21) (2009). Universidad del Rosario, Bogotá, Colombia, pp.259-275.

García, Y. (2008). Familias en Colombia: Transiciones hacia el siglo XXI. Barranquilla-Colombia: Editorial Corporación Educativa Mayor del Desarrollo Simón Bolívar.

Glaser, B. y Strauss, A. (1999). The Discovery of. Grounded Theory. Strategies for. Qualitative Research. Aldine 'flr msaction. A Division of Transaction Publishers. New Brunswick (U.S.A.) and London (U.K.). Library of Congress Catalogo number 66.28314.

González, F. (2010). Las autoridades de la UNAM: Una mirada de los estudiantes. En J. Piña (comp.). El cristal con que se mira. Diversas perspectivas metodológicas en educación. Madrid/México D.F.: /UNAN/Días de Santos.

Gough, K. (1982). Los nayar y la definición del matrimonio. El ori- 
gen de la familia. En Polémica sobre el origen y la universalidad de la familia (Quinta edición). Barcelona, España: Anagrama.

Gouh, K. (1989). Polémica sobre el origen y la universalidad de la familia (Quinta edición). Barcelona: Anagrama.

Hernández, R., Fernández, C., Baptista, M. (2014). Metodología de la investigación (Sexta edición). México: McGraw-Hill Education. Jodelet, D. (1986). La representación social: Fenómeno, concepto y teoría. Buenos Aires: Paidós.

Jodelet, D. (1993). La representación social: fenómenos, conceptos, teorías. En Moscovici, Psicología Social II: pensamiento y vida; psicología social y problemas sociales. Barcelona/Buenos Aires/México: Paidós.

Losada, A. (2008). Enfoques para el Análisis Político: Historia, epistemología y perspectivas de la ciencia política. Papel Político, 14(1), enero-junio, 2009. Bogotá, Colombia: Editorial Pontificia Universidad Javeriana.

Milbrath, L. \& Goel, M. (1977). Political Participation: How and Why Do People Get Involved in Politics? Paperback. USA: Rand McNally \& Co, pp.92-106.

Morales Castro, Y. (2015). Comportamiento electoral. Influencia determinante de los factores a corto plazo en la decisión del voto de los electores a la Alcaldía del municipio de Soledad (Atlántico) Colombia, año 2011. Justicia Juris, 11(1), 100-107. Moscovici, S. (1979). El psicoanálisis, su imagen y su público. Buenos Aires: Huemul.

Moscovici, S. (1984). Psicología Social: influencia y cambio de actitudes. Individuos y grupos (Primera edición). Barcelona: Paidós.

Moscovici, S. (1986). Psicología Social II. La representación social: fenómenos, concepto y teoría. Barcelona, España: Paidós. Parry, Moyser y Day (1992). Political Participation and democracy in Britain, Cambrige. Cambrige: University Press.

Percheron (1990). Produccion et transmision des valeurs au sein 
de la famille, en VV.AA. Du Politique et du social dans l'avenir de la famile. París: La documentation Francaise.

Quintero, Á. (1994). Introducción a la Familia como Sistema Social. Departamento de Trabajo Social, Universidad de Antioquia. Buenos Aires/Medellín: Editorial Lumen/Hvmanitas.

Ramírez, W. (2015). La guerra y el contrato social en Colombia. Primera Edición. Bogotá, Colombia: Penguin Random House. Ríos, P. \& Morales, Y. (2015). El proceso de socialización política transferido por las familias a los estudiantes de la Universidad Simón Bolívar del distrito de Barranquilla en el marco de la Democracia Colombiana (Trabajo de grado).

Tassara, M. (2005). El drama cultural argentino o por qué no somos un país serio (Primera edición). Buenos Aires, Argentina: Editorial Dunken.

Torcal, M. (2003). Political Disaffection in New Democracies. Notre Dame: Kellogg Institute.

Wagner, H., (2011). El discurso de lo cotidiano y el sentido común. La teoría de las representaciones sociales. Barcelona: Anthropos.

Wagner, W.; Kronberger, N. y Holtz, P. (2002). Collective Simbolic Coping with new Technology: Knowledge, Images and Public Discourse. British Journal of Social Psychology (41).

\section{Hemerográficas}

Arriagada, A. (2013). Clientelismo político y participación local. Polis, Revista Latinoamericana, 36(2). Recuperado el 24 de marzo de 2016 en https://polis.revues.org/9389

Barbeito, R. (2002). La familia y los procesos de socialización y reproducción sociopolítica de la juventud. Revista de Estudios de Juventud, 58. Editorial INJUVE. Recuperado de: http://www. injuve.es/sites/default/files/articulo6.pdf (2016, 24 de marzo).

Diccionario de la Lengua Española. Edición del Tricentenario. En http://dle.rae.es/?id=2aQCw98. Recuperado el día 5 de abril de 2016. 
Durkheim, E. (1898). Representations individuelles y representations collectives. Recuperado de: -300).https://www.google.com.

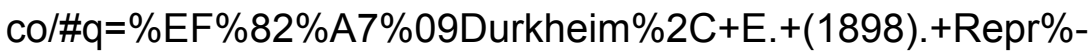
C3\%A9sentations+individuelles+et+repr\%C3\%A9sentations+collectives.+Revue+de+M\%C3\%A9taphysique+et+de+Morales.+En+D.+Emile\%2C+Repr\%C3\%A9sentations+individueIles+et+repr\%C3\%A9sentations+collectives \%22.+Revue+$\mathrm{de}+\mathrm{M} \% \mathrm{C} 3 \%$ A9taphysique+et+de+Morales+(Vol.+VI\%2C+p\%C3\%A1gs.+273-300) (2015, 20 de agosto).

Jiménez, G., A. y Arias Rodríguez, G. (2014). Las representaciones sociales y los medios masivos de comunicación: una vía de encuentro entre ambos conceptos. Recuperado de https:// www.google.com.co/?gws_rd=cr\&ei=f9ZNVtqCBYGDmQH$24 \mathrm{~J} 2 \mathrm{gAw \# q}=+($ Fern $\% \mathrm{C} 3 \% \mathrm{~A} 1 \mathrm{ndez} \% 2 \mathrm{C}+\ldots .+$ la + Revista + lberoamericana+de+Discurso+y+Sociedad $\% 2 C+e n+e l+2000 \%$ $2 \mathrm{C}+$ difunde+un+.....Page+19+ (2015, 20 de noviembre $)$.

Mamali, C. (2006). The Value of Images for Exploring the Functions of Social Representations: Towards Selfgenerated Pictorial social Representations. A comment on History, emotions and hetero-referential representations by Sen and Wagner (2005). Papers on social representations (1)15: 3.1-3.9. Recuperado de http://www.psych.Ise.ac.uk/psr/PSR2006/15_ 03Mamali.pdf (2015, 22 de mayo).

Ramírez, L. (2007). El funcionamiento familiar en familias con hijos drogodependientes. Un análisis etnográfico. Recuperado de http://www.uv.es/: http://www.uv.es/lisis/otras-publica/ tesis_lucia.pdf (05 de febrero de 2016) 